\title{
59. ROCK MAGNETISM OF BASEMENT ROCKS, DEEP SEA DRILLING SITE 417
}

\author{
Brigitte M. Smith, Laboratoire de Géomagntisme du Parc Saint-Maur, Saint-Maur, France \\ and \\ Ulrich Bleil, Institut für Geophysik, Ruhr-Universität Bochum, Germany
}

\section{INTRODUCTION}

Most magnetic studies on oceanic basalts, so far, were done on recent material dredged along the ridge axes, and on younger Cenozoic rocks drilled in different areas of the world oceans. Basement drilling at Site 417 has provided, for the first time, an opportunity to study in detail old oceanic crust and compare its magnetic properties with those of more recent oceanic crustal layers.

Although large differences in the degree of whole-rock alteration were noted between the highly altered material of Hole 417A and the remarkably fresh rocks of Hole 417D, no significant differences could be noted in the magnetic mineral chemistry between the two holes (Bleil and Smith, this volume). The titanomagnetites are generally moderately low temperature oxidized (from close to stoichiometric to $\mathrm{Z}$ $=0.8)$ in the massive units and more intensively altered $(0.6 \leqslant z \leqslant 1)$ in the pillows. The magnetic characteristics, nevertheless, were found to differ significantly between the two holes.

The magnetic properties of a rock mainly depend on the chemistry, the volume percentage, and the grain size of its magnetic mineral components. Along with microprobe chemical analysis, therefore, quantitative evaluations of their mean modal content and mean grain size were estimated by direct optical measurements and are shown in Table 1. However, as shown by previous studies and outlined in detail in this report, the proportion and the mean size of the magnetic oxides so determined do not seem to give a picture representative of the true magnetic mineral population present in an oceanic basalt. Due to limited resolution, the optically determined volumetric percentages will be generally underestimated, particularly in rapidly cooled rock units where submicroscopic grains are also likely to be present. For this reason and also because of delicate internal crack patterns and magnetic structures within the oxide minerals, the effective magnetic grain size may be smaller than indicated by direct optical methods.

The main aim of this chapter, therefore, is to overcome most of these difficulties by means of additional measurements of various relevant magnetic parameters.

\section{EXPERIMENTAL PROCEDURES}

Detailed descriptions of the equipment used for the basic magnetic measurements are given in Bleil and Smith (this volume): The intensity, $\mathrm{J}_{\mathrm{NRM}}$, of the natural remanent magnetization was measured on a Digico spinner magnetometer and the initial susceptibility, $\chi$, on a Bison magnetic susceptibility bridge.
Curie temperatures, $\mathrm{T}_{\mathrm{c}}$, were obtained from either the low field ( $1 \mathrm{Oe}$ ) temperature dependence of the initial susceptibility (Highmoor susceptibility bridge) or from experiments with a Forrer-type translation balance working at 1.8 koe (Bleil and Smith, this volume).

Isothermal saturation magnetization, $\mathrm{J}_{\mathrm{s}}$, saturation remanent magnetization, $\mathrm{J}_{\mathrm{rs}}$, bulk coercivity, $\mathrm{H}_{\mathrm{c}}$, and coercivity of remanence, $\mathrm{H}_{\mathrm{cr}}$, were determined for 29 samples (6 in Hole 417A and 23 in Hole 417D). The hysteresis cycles were performed on a translation inductometer to a maximum applied field of $1.6 \mathrm{koe} ; \mathrm{J}_{\mathrm{s}}$ was then obtained by an extrapolation method developed by Lecaille and Prévot (in preparation). The samples were then saturated in the 6.0-koe field of an electromagnet and $\mathrm{J}_{\mathrm{rs}}, \mathrm{H}_{\mathrm{c}}$, and $\mathrm{H}_{\mathrm{cr}}$ measured. It was noted that for many samples $\mathrm{J}_{\mathrm{rs}}$ values obtained after 1.6 and 6.0 koe (respectively) were identical indicating that the saturation of the ferrimagnetic minerals was almost complete at only 1.6 koe.

\section{RESULTS}

\section{General Magnetic Characteristics of Leg 51 Basalts}

Mean values for the intensity of the natural remanent magnetization, JNRM, the initial susceptibility, $\chi$, the Königsberger ratio, Q, and the viscosity coefficient, $v$, are summarized in Table 2 for each hole, excluding the bottom part of Hole 417D.

Whereas it is generally assumed that the NRM intensity decreases away from oceanic ridge axes as a result of low-temperature oxidation (Irving et al., 1970; Marshall and Cox , 1972), the values of JNRM presently observed in the Cretaceous oceanic crust at Site 417 are found to be about two to three times higher than at younger DSDP drilling sites and comparable to the intensities observed in the dredged basalts from mid-ocean ridges.

For drilled basalts of various ages ( 3 to $\sim 125$ m.y.B.P. from different locations in the world oceans, the geometric mean intensity of magnetization, JNRM, is generally between 1 and $3 \times 10^{-3} \mathrm{emu} / \mathrm{cm}^{3}$ (Lowrie [1974] on several legs in the Pacific and in the Atlantic Ocean; Grommé and Mankinen [1976] and Ade-Hall and Johnson [1976] on Leg 34; Bleil and Petersen [1977], Dunlop and Hale [1977], Murthy et al. [1977], and Ryall et al. [1977] on Leg 37; Petersen et al. [1978] on Legs 42 and 43; Johnson [1979] on Leg 45; Peterson [1979] on Leg 46). Basalts from Leg 49 have a slightly higher average JNRM $_{\text {as }}$ can be expected for young material drilled close to the Mid-Atlantic Ridge axis (Day et al., 1979).

Compared to these data, the unexpectedly high average $\mathrm{J}_{\mathrm{NRM}}$ of the 105 to 110 -m.y.-old Site 417 basalts is in closer 
TABLE 1

Average Modal Content (vol. \%) and Mean Grain Size $(\mu \mathrm{m})$ of
Oxide Minerals in Site 417 Basement Rocks; Viscosity Coefficient v (\%) According to Thellier and Thellier (1959)

\begin{tabular}{ccccc}
\hline & & \multicolumn{3}{c}{ Oxides } \\
Sample No. & $\begin{array}{c}\text { Rock } \\
\text { Type }\end{array}$ & $\mathrm{v}$ & Vol. \% & Grain \\
\hline
\end{tabular}

\section{Hole 417A}

24-5, 22-25

26-2, 39-42

28-1, 50-53

28-4, 44-46

29-2, 84-87

29-6, 83-85

$30-5,79-82$

32-1, 14-17

32-1, 56-59

$32-4,54-57$

$33-5,82-85$

34-1, 5-8

34-3, 29-32

34-5, 40-43

$35-4,7-9$

$35-4,106-109$

37-3, 23-25

$37-3,103-106$

$37-3,107-110$

37-5, 93-95

$38-2,8-11$

$38-2,18-21$

$38-2,28-31$

$38-2,38-41$

$38-2,48-51$

$38-4,34-37$

$38-4,49-51$

$39-1,37-40$

$39-4,24-27$

$39-4,81-83$

40-4, 67-69

41-1, 103-105

41-2, 68-70

$41-4,136-139$

41-5, 144-147

42-1, $18-20$

42-1, 63-66

43-2, 25-28

43-3, 118-121

43-4, 27-30

43-4, 105-108

$43-4,132-135$

$44-1,52-55$

44-1, 83-86

44-1, 132-135

44-2, 69-72

$44-2,140-143$

44-3, 8-11

44-3, $15-17$

44-3, 47-50

44-3, 96-99

46-1, 56-59

$\begin{array}{ccccc}\mathrm{p} & - & 0.8 & 4.2 & 28 \\ \mathrm{p} & 8.2 & - & - & 28 \\ \mathrm{p} & - & 0.4 & 3.4 & 28 \\ \mathrm{p} & 0.8 & - & - & 28 \\ \mathrm{p} & 0.1 & <0.1 & <1.0 & 29 \\ \mathrm{p} & - & 0.4 & 4.6 & 29\end{array}$

Hole 417D

21, CC

$22-2,107-110$

22-4, 18-21

26-2, 136-139

26-7, 6-9

27-5, 25-27

27-6, 86-89

28-3, 6-8

28-5, 135-138
28-5, 140-143

28-5, 145-148

28-6, 55-58

$28-7,15-18$

28-7, 28-30

$28-7,42-45$

$29-2,40-43$

29-2, 128-131

29-5, 9-11

30-1, 33-36

30-1, 89-92

$30-4,57-60$

30-5, 135-137

30-8, 3-6

31-1, 20-23

$31-4,100-103$

$31-4,108-110$

$31-4,115-118$

$31-4,119-121$

32-1, 53-56

$32-1,62-65$

$32-1,69-72$

32-1, 77-79

32-1, 111-112

32-1, 119-121

32-1, 137-140

$32-2,5-7$

32-2, 88-91

$32-3,12-14$

32-3, 44-47

$32-3,87-89$

32-3, 99-101

$32-4,6-9$

$32-4,113-116$

$32-5,6-9$

$32-5,57-60$

32-5, 103-106

$32-6,6-9$

$32-6,83-85$

32-6, 116-119

$32-7,11-14$

33-1, 41-44

33-1, 134-137

33-2, 55-57

33-2, 111-114

33-3, 27-30

33-3, 74-77

$33-4,27-30$

$33-4,77-80$

$33-4,132-135$

$33-5,29-32$

$33-5,75-78$

$33-5,119-121$

$33-5,126-128$

33-6, 22-25

34-1, 31-34

34-1, 106-109

TABLE 1 - Continued

\begin{tabular}{llll} 
& & \multicolumn{2}{c}{ Oxides } \\
Rock & & & Grain \\
Type & $\mathrm{V}$ & Vol. $\%$ & Size \\
\hline
\end{tabular}

$34-2,25-28$

34- $2,126-129$

34-3, 84-87

$34-4,20-23$

$34-4,65-68$

34-5, 34-37

34-5, 83-86

$34-5,100-103$

34-5, 117-121

$\begin{array}{rcc}0.9 & 0.3 & 1.2 \\ 0.6 & - & - \\ 0.6 & 0.6 & 2.8 \\ 2.1 & - & - \\ 1.9 & - & - \\ 8.6 & - & - \\ 0.3 & 0.1 & 1.6 \\ 0.5 & <0.1 & <1.0 \\ 1.0 & 0.2 & 2.4 \\ 1.0 & <0.1 & <1.0 \\ 0.5 & 0.1 & 1.8 \\ - & 0.6 & 3.0 \\ 1.9 & - & - \\ 0.5 & - & - \\ 1.9 & - & - \\ 4.9 & - & - \\ 16.9 & - & - \\ 0.8 & <0.1 & <1.0 \\ 0.9 & - & - \\ 3.5 & - & - \\ 1.1 & <0.1 & <1.0 \\ 8.6 & <0.1 & <1.0 \\ 1.3 & - & -\end{array}$

52

70

7.7

28.2
19.5

19.5

13.7

14.4

19.1

7.7

11.2

28.7

14.2

6.2

23.3

13.4

20.7

18.2

12.1

2.2

11.5

4.6

6.9

4.8

27.0

12.5

16.7

10.9

54

4.6

24.6

10.0

6.4

14.4

4.3

5.2

10.6

5.7

13.2

3.8

8.8

3.0

0.7

- 
TABLE 1 - Continued

\begin{tabular}{|c|c|c|c|c|}
\hline \multirow[b]{2}{*}{$\begin{array}{l}\text { Sample No. } \\
\text { (Interval in } \mathrm{cm} \text { ) }\end{array}$} & \multirow[b]{2}{*}{$\begin{array}{l}\text { Rock } \\
\text { Type }\end{array}$} & \multicolumn{3}{|c|}{ Oxides } \\
\hline & & v & Vol. \% & $\begin{array}{c}\text { Grain } \\
\text { Size }\end{array}$ \\
\hline \multicolumn{5}{|l|}{ Hole 417D } \\
\hline $34-5,124-126$ & $\mathrm{p}$ & 1.7 & 0.4 & 2.0 \\
\hline $36-1,138-140$ & $\mathrm{p}$ & 8.3 & - & - \\
\hline $37-3,88-91$ & $\mathrm{p}$ & - & 0.7 & 3.4 \\
\hline $37-4,41-44$ & $\mathrm{p}$ & 0.5 & - & - \\
\hline $37-7,21-24$ & $\mathrm{p}$ & 1.7 & 0.1 & 1.8 \\
\hline $38-1,38-40$ & $\mathrm{p}$ & 2.0 & - & - \\
\hline $38-5,115-118$ & $\mathrm{p}$ & 1.6 & 0.3 & 1.8 \\
\hline $38-5,132-134$ & $\mathrm{p}$ & 0.3 & - & - \\
\hline $39-2,109-112$ & $\mathrm{~m}$ & 9.5 & 1.1 & 4.6 \\
\hline $39-2,115-117$ & $\mathrm{~m}$ & 12.8 & - & - \\
\hline $39-3,5-8$ & $\mathrm{~m}$ & 68 & - & - \\
\hline $39-3,31-34$ & $\mathrm{~m}$ & 4.1 & 2.1 & 15.0 \\
\hline $39-3,39-42$ & $\mathrm{~m}$ & - & 2.6 & 15.0 \\
\hline $39-3,77-80$ & $\mathrm{~m}$ & 104 & - & - \\
\hline $39-5,48-51$ & $\mathrm{p}$ & 0.7 & 0.2 & 2.2 \\
\hline $39-5,57-60$ & $\mathrm{p}$ & - & $<0.1$ & $<1.0$ \\
\hline $39-5,66-69$ & $\mathrm{p}$ & 0.5 & 0.1 & 2.6 \\
\hline $40-1,37-40$ & $\mathrm{p}$ & 5.7 & 0.5 & 3.4 \\
\hline $40-1,101-103$ & $\mathrm{p}$ & 1.3 & - & - \\
\hline $40-2,132-134$ & $\mathrm{p}$ & 2.3 & - & - \\
\hline $40-2,143-145$ & $\mathrm{p}$ & 1.6 & - & - \\
\hline $41-1,109-112$ & $\mathrm{p}$ & 0.7 & $<0.1$ & $<1.0$ \\
\hline $41-3,19-22$ & $\mathrm{p}$ & 0.4 & - & - \\
\hline $41-3,75-78$ & $\mathrm{p}$ & 1.1 & 0.1 & 1.0 \\
\hline $41-5,10-13$ & $\mathrm{p}$ & 0.4 & - & - \\
\hline $41-5,50-52$ & $\mathrm{p}$ & - & 1.1 & 8.8 \\
\hline $41-6,18-21$ & $\mathrm{p}$ & 2.4 & 0.2 & 2.2 \\
\hline $41-6,137-139$ & $\mathrm{p}$ & 0.7 & - & - \\
\hline $42-1,60-62$ & $\mathrm{p}$ & 11.3 & - & - \\
\hline $42-1,64-67$ & $\mathrm{p}$ & 5.1 & $<0.1$ & $<1.0$ \\
\hline $42-1,86-88$ & $\mathrm{p}$ & 2.2 & - & - \\
\hline $42-1,105-107$ & $\mathrm{p}$ & - & 0.9 & 5.0 \\
\hline $42-1,126-129$ & $\mathrm{p}$ & 2.7 & - & - \\
\hline $42-1,131-134$ & $\mathrm{p}$ & 48 & - & - \\
\hline $42-1,137-140$ & $\mathrm{p}$ & 1.3 & - & - \\
\hline $42-5,41-43$ & p & 10.4 & - & - \\
\hline $42-6,35-37$ & $\mathrm{p}$ & 9.3 & - & - \\
\hline $42-6,82-84$ & $\mathrm{p}$ & 3.3 & - & - \\
\hline $42-6,127-130$ & $\mathrm{p}$ & 7.0 & 1.4 & 2.0 \\
\hline $43-1,88-91$ & $\mathrm{p}$ & 4.0 & - & - \\
\hline $43-2,140-142$ & $\mathrm{~m}$ & 25.4 & - & - \\
\hline $43-3,21-24$ & $\mathrm{~m}$ & 24.2 & 1.5 & 10.2 \\
\hline $43-3,63-66$ & $\mathrm{~m}$ & 6.4 & 1.6 & 17.2 \\
\hline $43-3,93-96$ & $\mathrm{~m}$ & 13.5 & 2.6 & 19.6 \\
\hline $43-4,48-51$ & $\mathrm{~m}$ & 19.1 & - & - \\
\hline $43-5,93-95$ & $\mathrm{~m}$ & - & 1.4 & 10.8 \\
\hline $43-6,13-15$ & $\mathrm{p}$ & - & 1.6 & 4.8 \\
\hline $43-6,92-94$ & $\mathrm{p}$ & 32.5 & - & - \\
\hline $44-1,37-40$ & $\mathrm{p}$ & 26.3 & 1.8 & 5.0 \\
\hline $44-1,46-49$ & $\mathrm{p}$ & 5.5 & 0.3 & 2.4 \\
\hline $44-1,134-136$ & $\mathrm{p}$ & 14.5 & 0.6 & 5.4 \\
\hline $44-2,31-34$ & $\mathrm{p}$ & 13.8 & - & - \\
\hline $44-2,81-84$ & $\mathrm{p}$ & 4.8 & 1.3 & 3.2 \\
\hline $44-4,99-101$ & $\mathrm{p}$ & 29.8 & - & - \\
\hline $44-5,3-6$ & $\mathrm{p}$ & - & 1.4 & 4.6 \\
\hline $45-1,27-30$ & $\mathrm{p}$ & 3.5 & 1.2 & 3.4 \\
\hline $45-1,100-102$ & $\mathrm{p}$ & 3.4 & - & - \\
\hline $45-2,16-19$ & $\mathrm{p}$ & - & 0.6 & 1.6 \\
\hline $48-5,38-41$ & $\mathrm{~m}$ & 7.0 & 1.5 & 11.6 \\
\hline $48-7,31-33$ & $\mathrm{~m}$ & 3.0 & - & - \\
\hline $49-1,21-23$ & $\mathrm{~m}$ & 2.5 & 0.7 & 6.8 \\
\hline $49-2,72-74$ & $\mathrm{~m}$ & 0.3 & 0.7 & 2.0 \\
\hline $50-2,65-67$ & $\mathrm{~m}$ & 8.0 & 1.8 & 20.6 \\
\hline $52-1,92-94$ & $\mathrm{~m}$ & 0.7 & 1.7 & 32.8 \\
\hline $52-6,57-59$ & $\mathrm{p}$ & 3.1 & 0.8 & 3.8 \\
\hline $54-2,135$ & $\mathrm{p}$ & 4.8 & 0.4 & 2.4 \\
\hline
\end{tabular}

TABLE 1 - Continued

\begin{tabular}{|c|c|c|c|c|}
\hline \multirow[b]{2}{*}{$\begin{array}{c}\text { Sample No. } \\
\text { (Interval in cm) }\end{array}$} & \multirow[b]{2}{*}{$\begin{array}{l}\text { Rock } \\
\text { Type }\end{array}$} & \multicolumn{3}{|c|}{ Oxides } \\
\hline & & $\mathrm{v}$ & Vol. \% & $\begin{array}{c}\text { Grain } \\
\text { Size }\end{array}$ \\
\hline \multicolumn{5}{|l|}{ Hole 417D } \\
\hline $54-4,55$ & $\mathrm{p}$ & 4.9 & 0.6 & 7.2 \\
\hline $55-2,16-18$ & $\mathrm{p}$ & 0.3 & 1.0 & 3.0 \\
\hline $55-4,87-89$ & $\mathrm{p}$ & 8.6 & 1.0 & 9.8 \\
\hline $57-1,79-82$ & $\mathrm{p}$ & 0.7 & 0.3 & 15.4 \\
\hline $57-2,16-19$ & $\mathrm{p}$ & 2.7 & 0.5 & 2.6 \\
\hline $59-4,99-102$ & $\mathrm{~b}_{\mathrm{c}}$ & 2.7 & 0.2 & 1.6 \\
\hline $59-6,33-35$ & $b_{c}$ & 1.0 & 0.8 & 11.0 \\
\hline $60-1,89-91$ & $\mathrm{~b}_{\mathrm{c}}$ & 4.9 & 0.8 & 4.6 \\
\hline $61-1,37-39$ & $\mathrm{~b}_{\mathrm{m}}$ & 3.4 & 0.8 & 9.6 \\
\hline $62-1,104-106$ & $\mathrm{p}$ & 3.9 & 0.6 & 3.4 \\
\hline $62-7,34-37$ & $\mathrm{p}$ & 0.5 & 0.5 & 3.4 \\
\hline $63-2,12-14$ & p & 5.3 & 1.6 & 17.0 \\
\hline $63-3,113-116$ & $\mathrm{p}$ & 6.2 & 0.4 & 6.2 \\
\hline $64-2,70-72$ & $\mathrm{p}$ & 1.9 & 0.8 & 3.0 \\
\hline $64-3,46-48$ & $\mathrm{p}$ & 0.6 & 0.2 & 1.4 \\
\hline $65-3,130-133$ & $\mathrm{~m}$ & 5.1 & 1.4 & 11.6 \\
\hline $65-6,79-81$ & $\mathrm{~m}$ & 0.5 & 1.7 & 18.2 \\
\hline $66-3,30-32$ & $\mathrm{p}$ & 4.1 & 1.6 & 14.8 \\
\hline $66-4,111-114$ & $\mathrm{p}$ & 0.5 & 0.4 & 2.2 \\
\hline $67-2,55-57$ & $\mathrm{~m}$ & 1.5 & - & - \\
\hline $67-6,12-14$ & $\mathrm{~m}$ & 3.4 & 1.1 & 10.4 \\
\hline $68-3,64-66$ & $\mathrm{~m}$ & 2.0 & 5.4 & 87 \\
\hline $68-5,89-92$ & $\mathrm{~m}$ & 1.3 & 3.7 & 41 \\
\hline $69-1,106-108$ & $\mathrm{~m}$ & 5.0 & 5.2 & 61 \\
\hline $69-2,35-37$ & $\mathrm{~m}$ & 2.2 & 4.1 & 55 \\
\hline
\end{tabular}

Note: $\mathrm{p}=$ pillow, $\mathrm{m}=$ massive, $\mathrm{b}_{\mathrm{c}}=$ breccia clast, $\mathrm{b}_{\mathrm{m}}=$ breccia matrix.

TABLE 2

Mean Values of Magnetic Properties for Site 417 Basement Rocks; Unit Weight Given to Individual Samples; Errors Listed are Standard Deviations of the Mean

\begin{tabular}{ccccc}
\hline JNR & \multicolumn{2}{c}{ Arithmetic Mean } & \multicolumn{2}{c}{ Geometric Mean } \\
& $417 \mathrm{~A}$ & $417 \mathrm{D}$ & $417 \mathrm{~A}$ & $417 \mathrm{D}$ \\
\hline${ }^{\mathrm{J}} \mathrm{NRM}$ & $9.43 \pm 9.47$ & $9.22 \pm 6.25$ & $6.53 \pm 2.38$ & $6.93 \pm 2.46$ \\
$\left(\times 10^{-3} \mathrm{emu} / \mathrm{cm}^{3}\right)$ & $\mathrm{N}=112$ & $\mathrm{~N}=159$ & $\mathrm{~N}=112$ & $\mathrm{~N}=159$ \\
$\times\left(\times 10^{-3} \mathrm{emu} / \mathrm{cm}^{3} \cdot \mathrm{Oe}\right)$ & $0.94 \pm 0.76$ & $1.80 \pm 0.83$ & $0.70 \pm 2.15$ & $1.52 \pm 1.97$ \\
& $\mathrm{~N}=106$ & $\mathrm{~N}=205$ & $\mathrm{~N}=106$ & $\mathrm{~N}=205$ \\
$\mathrm{Q}$ & $26.8 \pm 17.3$ & $18.2 \pm 18.5$ & $20.5 \pm 2.4$ & $11.4 \pm 2.9$ \\
$\mathrm{v}$ & $\mathrm{N}=105$ & $\mathrm{~N}=158$ & $\mathrm{~N}=105$ & $\mathrm{~N}=158$ \\
$\%$ & $4.1 \pm 8.1$ & $10.6 \pm 15.5$ & $1.0 \pm 5.9$ & $4.5 \pm 4.1$ \\
$\mathrm{~N}=41$ & $\mathrm{~N}=120$ & $\mathrm{~N}=41$ & $\mathrm{~N}=120$ \\
\hline
\end{tabular}

Note: $J_{N R M}=$ intensity of natural remanent magnetization; $x=$ initial susceptibility; $Q=$ Königsberger ratio; $v$ = viscosity coefficient according to Thellier and Thellier (1959).

agreement with magnetic intensities found in recent material (ages $<5 \times 10^{5} \mathrm{yr}$ ) dredged from the Mid-Atlantic Ridge axis (compilations by Lowrie, 1974; for the $45^{\circ} \mathrm{N}$ region; by Lecaille and Prévot, in preparation, for the FAMOUS area, $37^{\circ} \mathrm{N}$ ). According to the previously cited authors, the initial susceptibilities, $\chi$, of oceanic basalts usually vary between 0.2 and $2 \times 10^{-3} \mathrm{emu} / \mathrm{cm}^{3} \cdot$ Oe and are the lowest in the more recent basalts. The mean $\chi$ of the Site 417 basalts, although falling in the range observed at other drilling sites, is still among the highest values. It must be noted, however, that J JRM and more specifically $\chi$, primarily depend on the lithologic type of basalt drilled (pillows or massive units).

The magnetic minerals at Site 417 exhibit a chemistry rather typical of oceanic basalts and a generally high degree of 
low-temperature oxidation (Bleil and Smith, this volume). This type of alteration is thought to reduce appreciably the spontaneous magnetization; therefore, the high values of $\mathrm{J}_{\mathrm{NRM}}$ and $\chi$ at Site 417, when compared to other DSDP results, cannot be attributed to chemical composition.

The Königsberger ratio, Q, can be considered (to a first approximation) to reflect the magnetic grain-size range. While high for small magnetic particles $(\bar{Q}=151$ in the FAMOUS area, Lecaille and Prévot, in preparation), Q decreases with increasing grain sizes $(2<\bar{Q}<40)$ for drilled oceanic basalts. Similarly, JNRM increases with decreasing effective magnetic domain size down to the superparamagnetic limit. As the average, Q for Site 417 materials is in general agreement with values of formerly drilled basalts; it seems unlikely that the present magnetic oxides on the average comprise a distinctly smaller grain size range. Instead, the actually observed higher values of JNRM and $\chi$ can rather be accounted for by larger volumic percentage of magnetic oxides at Site 417 than at other drilling sites.

\section{Pillows and Massive Units}

According to the classification based on the grain size and the degree of oxidation of the magnetic minerals (Bleil and Smith, this volume), a distinction can be made between the pillows and the massive units in each hole. Histograms of the logs of J $\mathrm{JRM}_{\text {NR }}$ (Figure 1), $\chi$ (Figure 2), and Q (Figure 3) are given for a total of more than 300 samples, excluding the bottom part of Hole 417D. Figure 4 shows the distribution of $v$ for 160 samples.

Significant differences in $\mathrm{J}_{\mathrm{NRM}}, \chi, \mathrm{Q}$, and $\mathrm{v}$ exist between the pillow basalts of Hole 417A and those of Hole 417D. In the massive units of both holes, a similar distribution was obtained only for $\chi$, whereas the $\mathrm{J}_{\mathrm{NRM}}, \mathrm{Q}$, and $\mathrm{v}$ ranges are markedly different. Furthermore (and somewhat unexpectedly in view of the distinction made between pillows and massive basalts), the histograms of $\mathrm{J}_{\mathrm{NRM}}, \mathrm{Q}$, and possibly $\mathrm{v}$ for the Hole 417D pillows and the Hole 417A massive basalts are comparable.

Consistent with the microscopically observed differences in the degree of crystallization, the titanomagnetites in the massive units have larger magnetic grain sizes than those in the pillows as attested by the $\mathrm{Q}$ values and also the median destructive field (MDF) data (Figures 5 and 6). Moreover, the magnetic minerals constitute a larger volume percentage in the massive units than in the pillows, as can be noted from the microscopic evaluation in Table 1 and will be presently demonstrated by the higher values of $\chi$. It has been shown (Bleil and Smith, this volume) that the degree of oxidation of the magnetic minerals, although variable inside a single unit, is statistically different between pillows and massive units, but comparable within the pillow and massive basalts of the two holes. Assuming the chemical composition to be constant for a given rock type, the differences in $\mathrm{J}_{\mathrm{NRM}}, \chi, \mathrm{Q}, \mathrm{v}$, and MDF can be essentially attributed to variations in the percentage and the size of the magnetic minerals.

A comparison of JNRM and $\chi$ between the pillows of both holes indicates that the magnetic grains are more abundant in Hole 417D than in Hole 417A. Concerning the size ranges however, the evidence is less clear, considering that in pillow basalts the magnetic minerals commonly span the

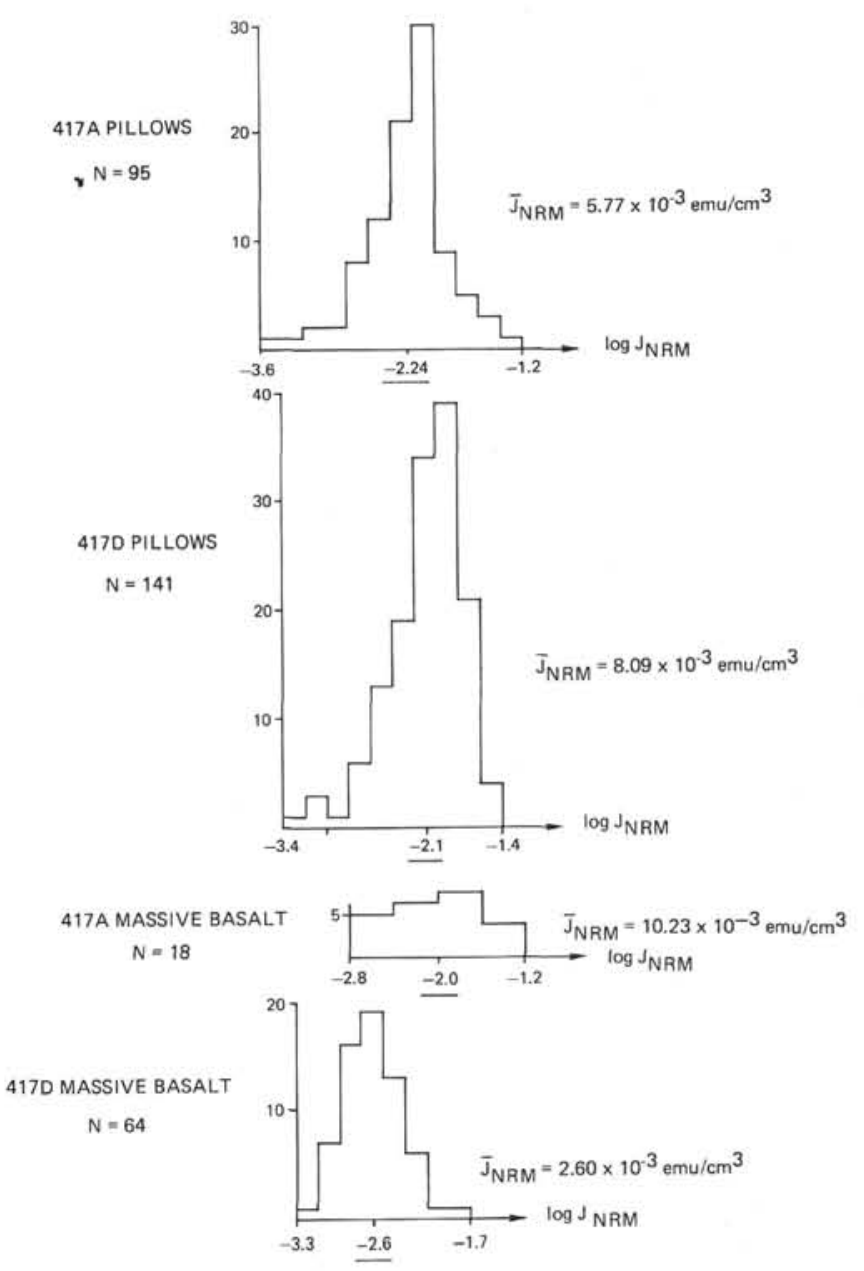

Figure 1. Histograms of the natural remanent magnetization intensity $J_{N R M}\left(\times 10^{-3} \mathrm{emu} / \mathrm{cm}^{3}\right)$ for pillow and massive basalt samples from Holes $417 A$ and $417 D$.

single domain to pseudo-single domain range. $\mathrm{Q}$ and MDF are higher in Hole 417A than in Hole 417D which suggests that the grains are smaller in Hole 417A. V, on the other hand, is slightly higher in Hole 417D (Table 1, Figure 4), which suggests that grains of short relaxation times, close to the superparamagnetism/single domain threshold are present. If such grains were also present in the Hole 417A pillows, a higher magnetic viscosity would be expected than is actually observed.

A similar comparison for the $\chi$ values between the massive units of both holes again seems to indicate a slightly larger percentage of magnetic minerals in Hole 417D. At first glance, this observation is contradicted by the $\mathrm{J}_{\mathrm{NRM}}$ values recorded in the two holes, since $\mathrm{J}_{\mathrm{NRM}}$ is five times lower in Hole 417D. In fact, however, the massive basalts in Hole 417D were found to have acquired a secondary magnetization component of normal polarity (Bleil and Smith, this volume). Since viscosity tests proved these samples to be highly viscous (Table 1, Figure 4), this magnetization secondary component appears to be caused by VRM. Since the TRM and VRM components are more or less oppositely polarized, the resultant NRM intensity is comparatively low. As a consequence of the low $\mathrm{J}_{\mathrm{NRM}}$ and high $\chi$ values, $Q$ is appreciably reduced in the massive units 


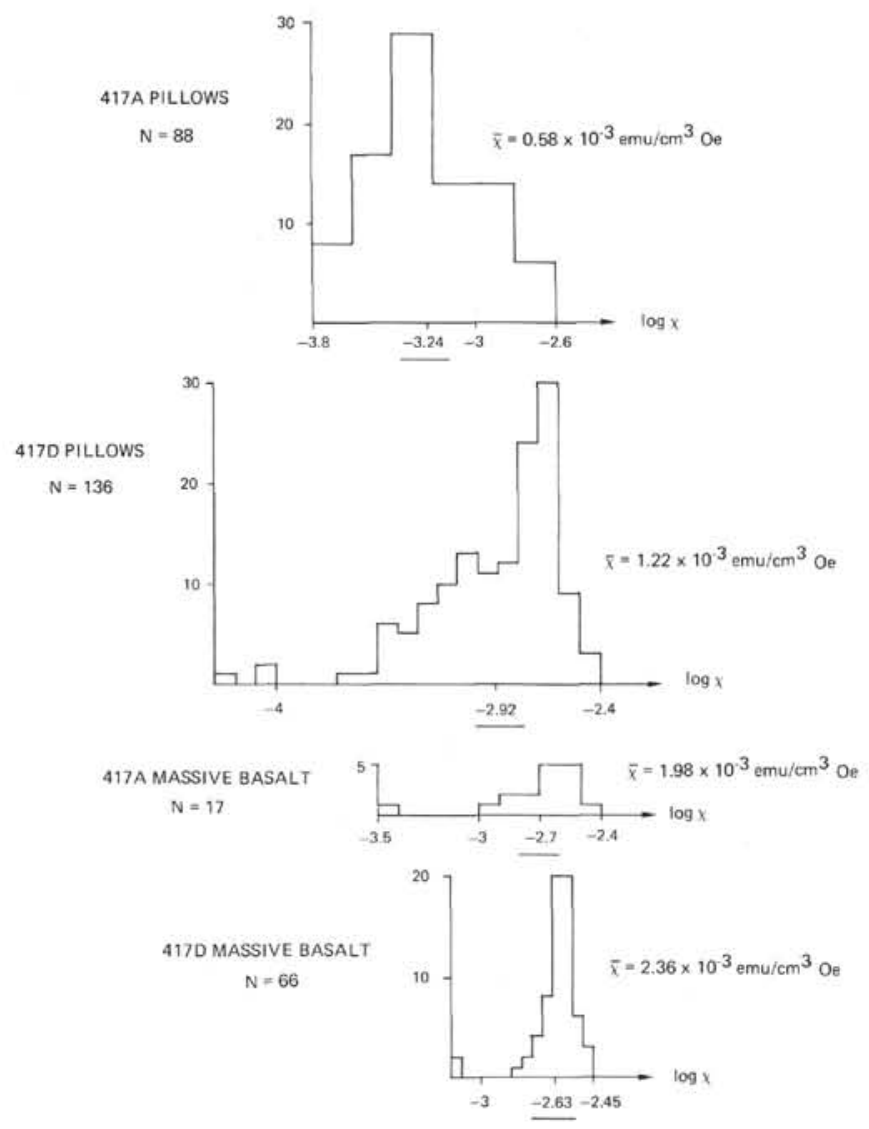

Figure 2. Histograms of the initial susceptibility, $\chi\left(\times 10^{-3}\right.$ emu/cm $\mathrm{cm}^{3}$ - Oe) for pillow and massive basalt samples from Holes $417 \mathrm{~A}$ and $417 \mathrm{D}$.

of Hole 417D, and due to the multicomponent nature of the NRM in this specific case, does not accurately reflect the ranges of grain size observed in the two holes. Figure 7 illustrates the negative correlation existing between the viscosity coefficient and the Königsberger ratio for Site 417 basement rocks.

\section{Downhole Variation of Magnetic Properties}

Downhole plots of the basic magnetic parameters $\mathrm{J}_{\mathrm{NRM}}, \chi$, and MDF are given in Figures 5 and 6 (see also Bleil and Smith, this volume).

The 195 meters of basalts drilled in Hole 417A include about 174 meters of pillowed flows and a single massive unit about 21 meters thick. Due to the fact that the samples were taken in varying locations within different cooling units, the sampling itself is partially responsible for the observed scatter in the data since the sizes, the percentage, and the degree of oxidation of the magnetic oxides are known to vary significantly from the outer rim towards the center of individual pillows (Watkins et al., 1970; Marshall and Cox, 1972), and to vary in a similar manner but to a lesser degree in the massive units.

In the Hole 417A pillows (Figure 5), JNRM and $\chi$ reveal a rather limited range of variability in the upper 100 meters (between 218 and $305 \mathrm{~m}$ sub-bottom), whereas MDF in the same interval decreases regularly from almost 400 to about $100 \mathrm{Oe}$, probably as a result of an increase in the magnetic
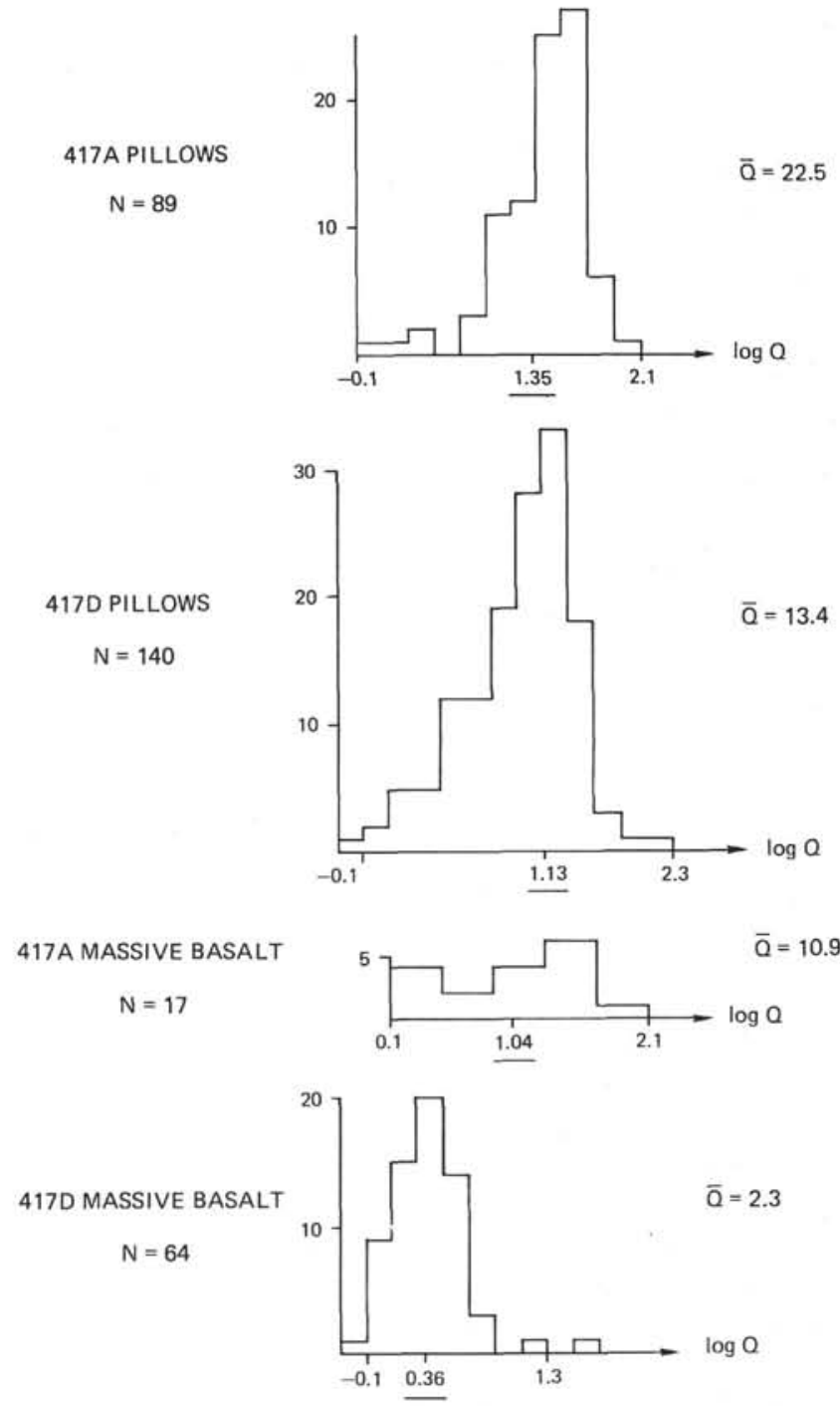

Figure 3. Histograms of the Königsberger ratio, $Q$, for pillow and massive basalt samples from Holes $417 \mathrm{~A}$ and $417 D$.

grain sizes. Between 305 and 388 meters sub-bottom, $\mathrm{J}_{\mathrm{NRM}}$ and $\chi$ are significantly more scattered around slightly higher mean values. The positive correlation observed between the averages of JNRM and $\chi$ for the various magnetic units may best be interpreted in terms of variations in the magnetic oxide percentages. If this is the case, the negative correlation in this interval between $\mathrm{J}_{\mathrm{NRM}}$ and $\chi$ on the one hand, and MDF on the other, again corroborates the assertion that the more abundant the magnetic oxides (and thus the higher the values of $\mathrm{J}_{\mathrm{NRM}}$ and $\chi$ ), the larger the magnetic grain sizes (the lower the MDF).

In the $417 \mathrm{~A}$ massive unit ( 388 to $408 \mathrm{~m}$ sub-bottom), a distinction can be made according to viscosity characteristics. In the upper part ( 388 to $396 \mathrm{~m}$ ) where the viscosity coefficient $\mathrm{v}$ is negligible and no appreciable secondary component of magnetization is present, the values of $\mathrm{J}_{\mathrm{NRM}}$ are high. The lower part of the Hole 417A massive unit, on the other hand, is characterized (like the massive units in Hole 417D) by distinctly higher values of v (10 to $30 \%$ ), the presence of a secondary component of magnetization, and 

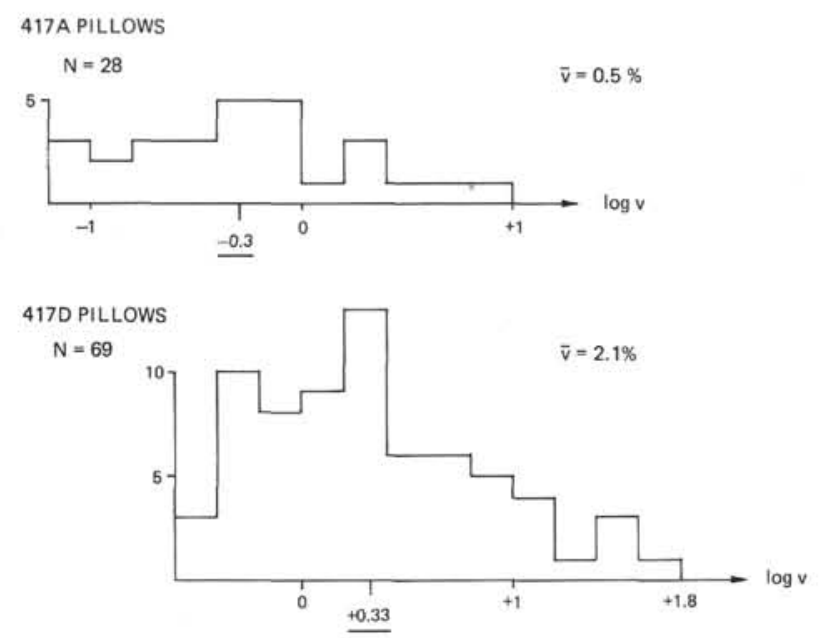

417A MASSIVE BASALT

$N=12$
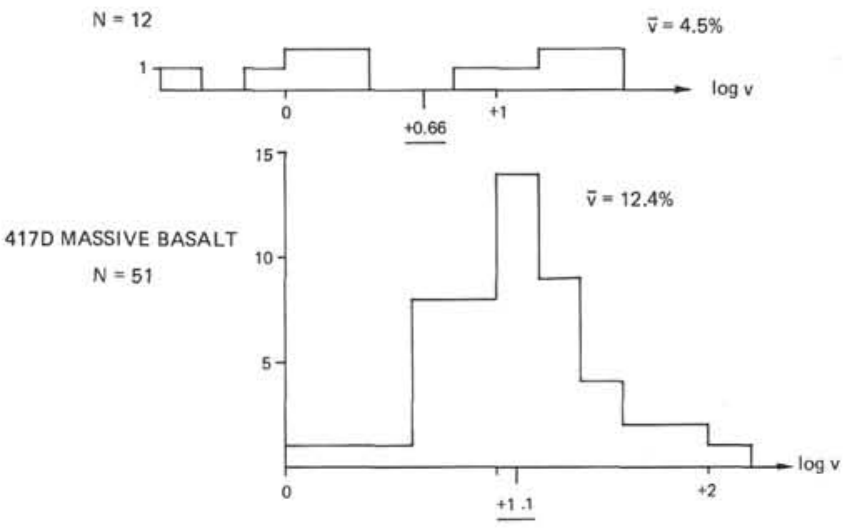

Figure 4. Histograms of the viscosity coefficient, $v$, for pillow and massive basalt samples from Holes $417 \mathrm{~A}$ and $417 D$.

low values of JNRM as a result of the opposing effects of a reverse thermoremanence (TRM) and a normal in situ viscous remanent magnetization (VRM). Moreover, the susceptibilities are higher than in the upper part of the massive unit, probably due to the presence of more numerous and larger magnetic grains of the multidomain range responsible for the viscous magnetization.

Only a very limited amount of paleosecular field variation has been recorded in the Hole 417A basement section. It is thus probable that this whole basaltic sequence was emplaced in a short period of time during which the general chemical composition of the basaltic magma source did not change considerably; this could account for the rather small differences in mean JNRM and $\chi$ values observed between the different magnetic units. Minor downhole trends in the data seem to be best explained by variations in the cooling rates of the individual magnetic units.

More pronounced differences both in the secular field variation and in the magnetic properties are recorded in Hole 417D. The 170 meters studied here are built of a thick series of pillows representing about 80 per cent of the section interlayered with three massive basalt units constituting about 20 per cent of the section.

In the upper series of Hole 417D pillows (339 to $413 \mathrm{~m}$ sub-bottom), a general decrease of $\mathrm{J}_{\mathrm{NRM}}$ and $\chi$ is observed
(Figure 6) corresponding to an overall trend of decreasing magnetic oxide percentages with increasing depth. The mean MDF values of the magnetic units in this interval, although highly scattered, are thought to reflect the actual variation in average magnetic grain sizes, since most of the unit means are based on a large number of individual measurements.

From 435 to 465,468 to 495 , and 502 to 515 meters sub-bottom, the pillow basalts (interrupted by two thin massive units) display a general trend of decreasing JNRM and MDF, and increasing $\chi$ with depth. In contrast to the pattern observed in Hole 417A and in the upper pillow section of Hole 417D, a negative correlation is apparent in these units between $\mathrm{J}_{\mathrm{NRM}}$ and $\chi$. Along with decreasing MDF and increasing $\mathrm{v}$, this may be explained by assuming an increasing amount of single domain (SD) particles close to the superparamagnetic (SPM) threshold. These particles would be characterized by a high susceptibility and relaxation times too short to have kept the original TRM, but long enough to acquire a VRM component in a short period of time.

In the Hole 417D massive units ( 413 to 435,465 to 468 , and 495 to $501 \mathrm{~m}$ sub-bottom), all values are more tightly grouped than in the pillows. The MDF is low (usually $<100$ Oe) but cannot be defined accurately due to the presence of a large VRM component superimposed on the TRM. The susceptibilities are high because the magnetic mineral grains are large but mainly because they represent an appreciable volume percentage of the samples. As already discussed above, low values of J $J_{\mathrm{NRM}}$ in these units can be explained by high viscosity coefficients.

\section{Characteristics of Magnetic Hysteresis Cycles}

The isothermal saturation magnetization $\mathrm{J}_{\mathrm{s}}$, the saturation remanent magnetization $\mathrm{J}_{\mathrm{rs}}$, the $\mathrm{J}_{\mathrm{rs}} / \mathrm{J}_{\mathrm{s}}$ ratio, the coercive force $\mathrm{H}_{\mathrm{c}}$, the remanence coercivity $\mathrm{H}_{\mathrm{cr}}$, and the $\mathrm{H}_{\mathrm{cr}} / \mathrm{H}_{\mathrm{c}}$ ratio are summarized in Table 3 along with values of MDF, Q, and $\mathrm{v}$ for 29 samples, including 7 samples from the bottom part of Hole 417D.

$\mathrm{J}_{\mathrm{s}}$ is of special interest since, for a given chemical composition, it only depends on the volume percentage of the magnetic minerals present. Compared to the average values obtained on other oceanic basalts (Lecaille and Prévot, in preparation; Grommé and Mankinen, 1976; Ade-Hall et al., 1976; Dunlop and Hale, 1977; Bleil and Petersen, 1977; Petersen et al., 1978, in press; Johnson, 1979; Petersen, 1979; Day et al., 1979), Js is generally higher at Site 417 , which bears out the assertion that an unusually large percentage of magnetic minerals is present in the Site 417 basalts. Thus for example, the highly oxidized titanomagnetites found in pillow samples in Holes $417 \mathrm{~A}$ and $417 \mathrm{D}$ cause the samples to have an average $\bar{J}_{\mathrm{s}}$ of $1.38 \pm 0.88 \mathrm{emu} / \mathrm{cm}^{3}$ for 17 samples, 1.5 times higher than the average obtained for 53 fresh pillow basalt samples from the FAMOUS area $\left(0.87 \pm 0.11 \mathrm{emu} / \mathrm{cm}^{3}\right.$; Lecaille and Prévot, in preparation), which implies a significantly higher amount of magnetic minerals in the first case. As already noted, the magnetic fraction appears to be more abundant in Hole 417D than in Hole 417A. In fact, a clear difference exists between the average $\overline{\mathrm{J}}_{\mathrm{s}}$ for pillows from Hole $417 \mathrm{~A}$ $\left(0.53 \pm 0.09 \mathrm{emu} / \mathrm{cm}^{3} ; 4\right.$ samples) and Hole 417D (1.64 $\pm 0.85 \mathrm{emu} / \mathrm{cm}^{3} ; 13$ samples) which cannot be explained by 


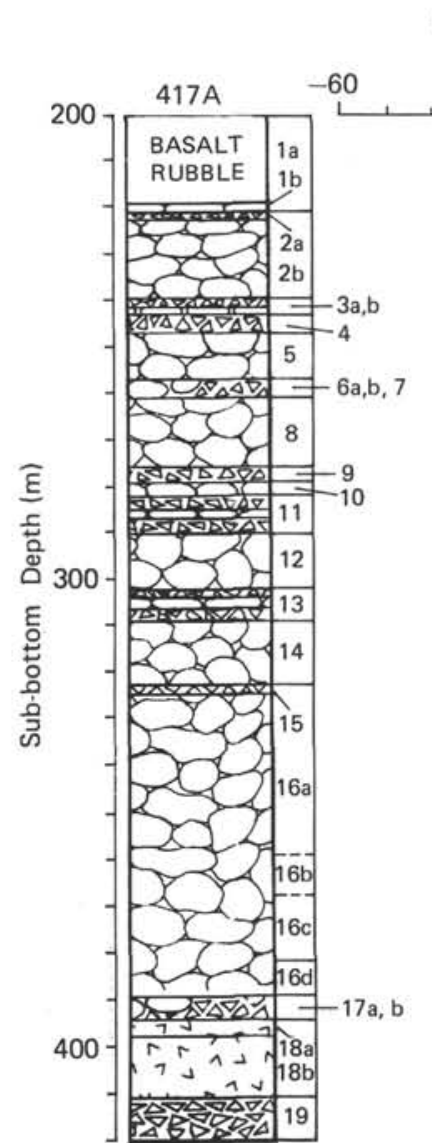

Istable
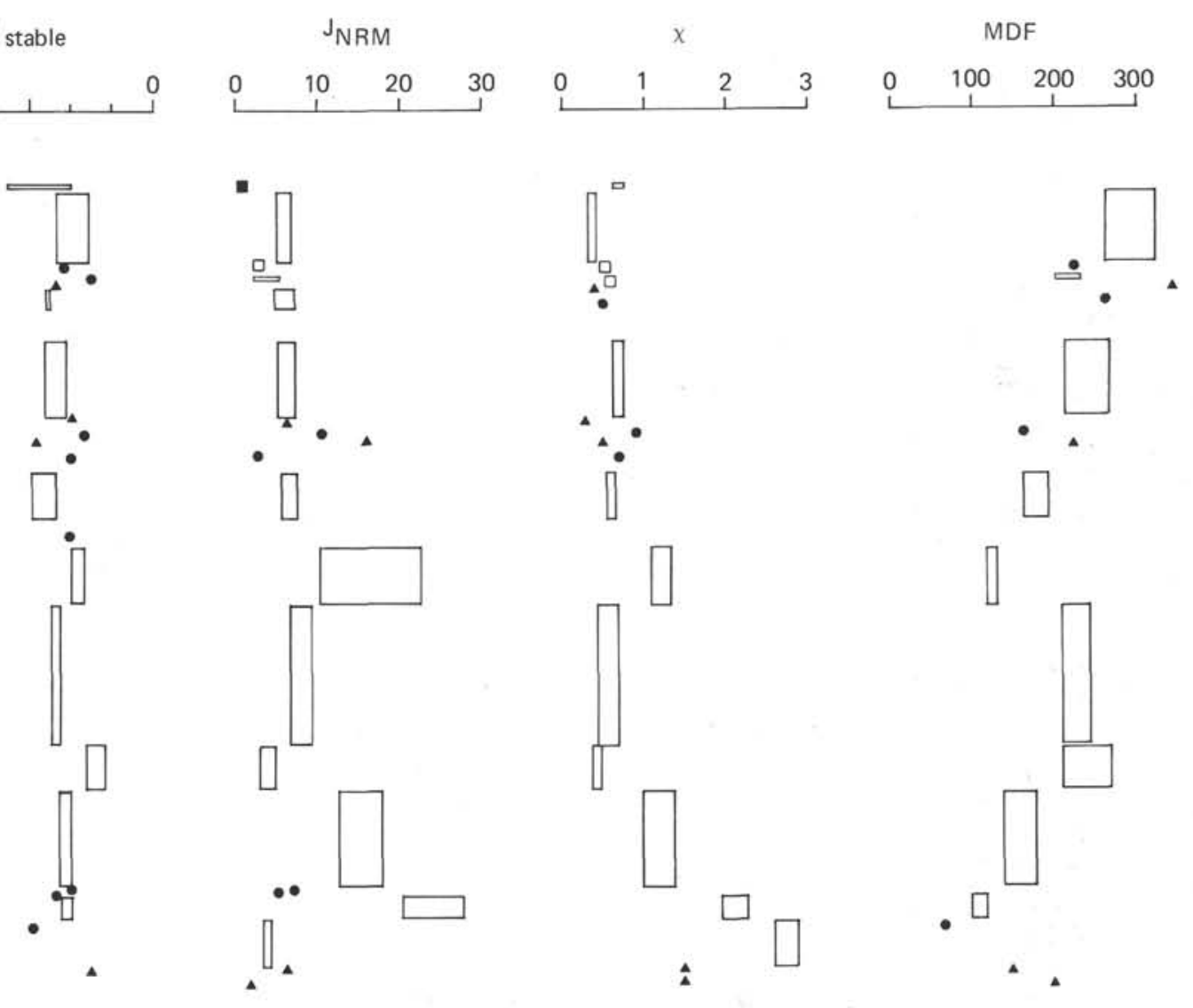

Figure 5. Properties of magnetic units and individual samples for Hole 417A. The length and width of the bars, respectively, indicate the thickness of each magnetic unit and the standard deviation of the mean. Individual samples: circles = pillow

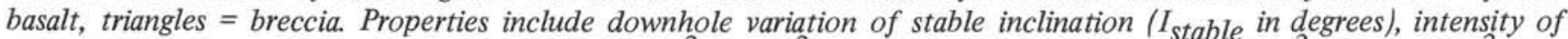
natural remanent magnetization $\left(J_{N R M}\right.$ in emu $\left./ \mathrm{cm}^{3} \times 10^{-3}\right)$, initial susceptibility $\left(\chi\right.$ in emu/cm $\left.\mathrm{em}^{3} \cdot 0 \mathrm{e} \times 10^{-3}\right)$ and median destructive field ( $M D F$ in $\mathrm{Oe}$ ).

differences in chemical composition (Bleil and Smith, this volume) but rather, must be attributed to a greater abundance of magnetic oxides in the second hole. Although based here on a limited number of measurements, this interpretation is supported by the $\mathrm{J}_{\mathrm{NRM}}$ and $\chi$ values recorded on more than 300 samples. A similar difference is also observed between the massive basalt samples of the two holes, $\overline{\mathrm{J}}_{\mathrm{s}}$ averaging $2.02 \pm 0.53 \mathrm{emu} / \mathrm{cm}^{3}$ (2 samples) in Hole $417 \mathrm{~A}$ and $3.33 \pm 0.47 \mathrm{emu} / \mathrm{cm}^{3}$ (10 samples) in Hole $417 \mathrm{D}$ with the difference being attributed to variations in the oxidation and percentage of magnetic oxides. It should be noted that these values of $\mathrm{J}_{\mathrm{s}}$ are approximately twice as high as in the pillows.

A positive correlation is observed at Site 417 between $J_{s}$ and $J_{\text {NRM }}$ (Figure 8) for pillows and massive basalt samples from Hole 417A, and for pillows from Hole 417D. The high $\mathrm{J}_{s}$ and low $\mathrm{J}_{\text {NRM }}$ values in some massive basalt samples from Hole 417D demonstrate, as already proposed, that a relatively large percentage of magnetic minerals is present in these rocks of which only a part contributes to the original reversed thermoremanent magnetization, while a relatively large proportion contributes to in situ viscous remanent magnetization in the opposite direction. A similar relation exists between $J_{s}$ and $\chi$ (Figure 9), but here all of the magnetic grains of the viscous massive basalt samples from Hole 417D contribute to the initial susceptibility.

Figures 8 and 9 mainly reflect the volume percentage variations of the magnetic oxides at Site 417 . This parameter evidently varies to a higher degree within the pillows of Hole 417D than of Hole 417A, as far as only four samples are representative of the latter.

Independent of concentration, the ratio $\mathrm{J}_{\mathrm{rs}} / \mathrm{J}_{\mathrm{s}}$ is a sensitive indicator of the grain sizes of the magnetic minerals present. Stoner and Wohlfarth (1948) and Néel (1954), by means of theoretical calculations, predict for single-domain particles of nonoxidized titanomagnetites $\mathrm{J}_{\mathrm{rs}} / \mathrm{J}_{\mathrm{s}}$ to be 0.5 if the anisotrophy is unaxial (i.e., of stress or shape origin) and 0.8 if it is of magnetocrystalline origin.

Experimentally, $\mathrm{J}_{\mathrm{rs}} / \mathrm{J}_{\mathrm{s}}$ was found slightly to exceed 0.5 for synthetic samples containing SD titanomaghemite particles (O'Donovan and O'Reilly, 1977) and to approach 0.7 in some of the Leg 49 samples (Day et al., 1979). It is also observed that $\mathrm{J}_{\mathrm{rs}} / \mathrm{J}_{\mathrm{s}}$ decreases with increasing grain size and values lower than about 0.1 to 0.05 are considered to be characteristic of multidomain grains.

No significant differences in $\mathrm{J}_{\mathrm{rs}} / \mathrm{J}_{\mathrm{s}}$ data exist between the pillows and massive samples of Hole 417A and the pillows of Hole $417 \mathrm{D}$, where $\mathrm{J}_{\mathrm{rs}} / \mathrm{J}_{\mathrm{s}}$ is generally close to 0.3 . In the 


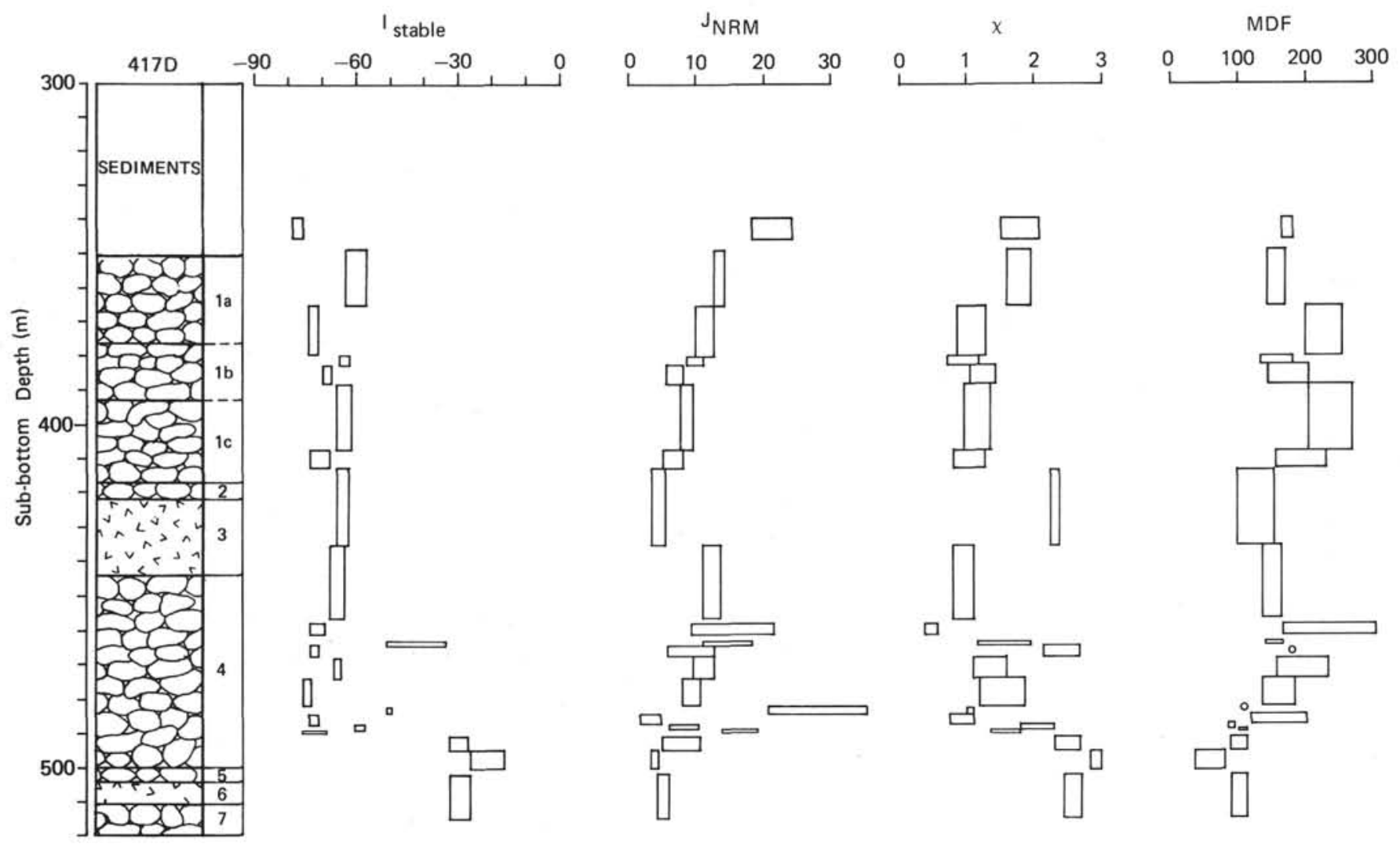

Figure 6. Properties of magnetic units and individual samples for Hole 417D. The length and width of the bars, respectively, indicate the thickness of each magnetic unit and the standard deviation of the mean. Individual samples: circles = pillowed basalt. Properties include downhole variation of stable inclination ( $I_{\text {stable }}$ in degrees), intensity of natural remanent magnetization $\left(J_{N R M}\right.$ in emu $\left./ \mathrm{cm}^{3} \times 10^{-3}\right)$, initial susceptibility $\left(\chi\right.$ in emu/cm $\left.3 \cdot 0 e \times 10^{-3}\right)$ and median destructive field (MDF in $\mathrm{Oe})$.

massive basalts of Hole $417 \mathrm{D}, \mathrm{J}_{\mathrm{rs}} / \mathrm{J}_{\mathrm{s}}$ averages only 0.12 . These values are too low in the first group to be due to SD particles alone and are generally too high in the second group to be exclusively accounted for by MD grains. Therefore, pseudo-single domain grains are likely to be present in both cases.

The interpretation of bulk coercivity, $\mathrm{Hc}$, measurements in terms of magnetic grain size is less conclusive, as it also depends on the chemistry and the type of anisotropy in the magnetic oxides. Nevertheless, it is now well established that $\mathrm{Hc}_{\mathrm{c}}$ increases with decreasing grain size from the MD to SD state, and further decreases within the single-domain range, at first gradually near the upper SD limit and then drastically near the superparamagnetic (SPM) threshold (Herpin, 1968).

At Site 417, a clear difference exists between the coercive forces of the pillows and the massive basalts. In the pillows of Holes 417A and 417D, the $\mathrm{Hc}_{\mathrm{c}}$ values average around 150 $\mathrm{Oe}$, and are thus significantly lower than SD values and about half the mean value obtained on fresh pillow basalts from the FAMOUS area (Lecaille and Prévot, in preparation). Since the titanomagnetites in the pillows at Site 417 are strongly low-temperature oxidized, it is likely that their fragmentation by volume change cracks produces an increase of the superparamagnetic fraction resulting in a decrease of Hc. Moreover, as suggested by Butler (1973), low-temperature oxidation will cause the SD grains with initially low blocking temperatures to become superparamagnetic. This mechanism, particularly efficient for titanomagnetites with $x=0.6$ (Butler, 1973), would also contribute to the decrease in coercivity.

In the massive units of Holes 417A and 417D, $\mathrm{Hc}$ averages around $50 \mathrm{Oe}$, a typical value for MD grains, but also for a SD/MD mixture containing a smaller proportion $(<50 \%)$ of the hard fraction (Day et al., 1977). Such a mixture is likely to be realized in the massive basalt samples where two generations of titanomagnetites have been observed (Bleil and Smith, this volume) and where the large crystals exhibit numerous volume change cracks.

The remanence coercivity, $\mathrm{H}_{\mathrm{cr}}$, of a mixture of both soft and hard fractions, will be dominated by the hard fraction (Day et al., 1977) even when only a small proportion of SD particles is present. Figure 10 illustrates the positive correlation existing at Site 417 between $\mathrm{H}_{\mathrm{cr}}$ and MDF, both of which are sensitive indicators of the remanence stability and thus of the magnetic grain size. This diagram again gives clear evidence that the magnetic mineral sizes vary much more within the Hole 417D pillows than within the Hole 417A pillows and the massive units of either hole.

Further information on the magnetic grain sizes can be obtained from the ratio $\mathrm{Hcr}_{\mathrm{c}} / \mathrm{H}_{\mathrm{c}}$. For a random assemblage of non-interacting unaxial SD grains, theory predicts that 


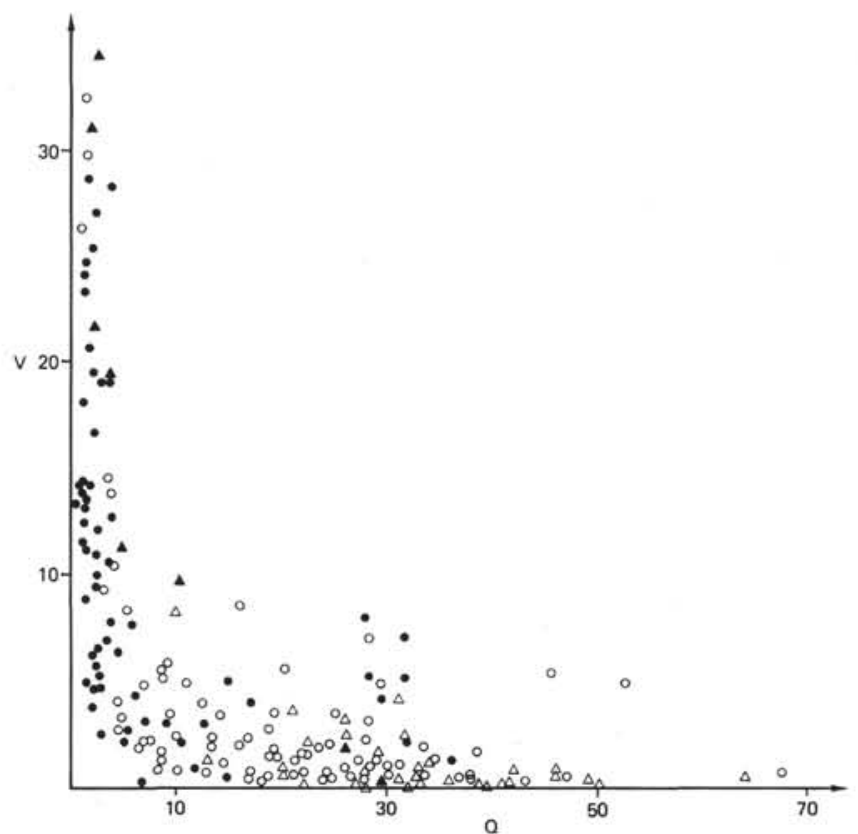

Figure 7. Relationship between viscosity coefficient $v(\%)$ and Königsberger ratio $Q$ for Site 417 basement rocks. $\triangle=$ pillow basalts from Hole $417 \mathrm{~A} ; 0$ = pillow basalts from Hole 417D; $\mathbf{\Lambda}=$ massive basalts from Hole $417 A$; - massive basalts from Hole 417D.

TABLE 3

Hysteresis Cycle Characteristics of Site 417 Basement Rocks

\begin{tabular}{|c|c|c|c|c|c|c|c|c|c|}
\hline & $\mathrm{J}_{\mathrm{s}}$ & $\mathrm{J}_{\mathrm{rS}}$ & $\mathrm{J}_{\mathrm{rs}} / \mathrm{J}_{\mathrm{s}}$ & $\mathrm{H}_{\mathrm{c}}$ & $\mathrm{H}_{\mathrm{cr}}$ & $\mathrm{H}_{\mathrm{cr}} / \mathrm{H}_{\mathrm{c}}$ & MDF & Q & $v$ \\
\hline \multicolumn{10}{|l|}{ 417A Pillows } \\
\hline $35-4,7-9$ & 0.550 & 19.8 & 0.36 & 182 & 261 & 1.43 & 234 & 39 & 0 \\
\hline $37-3,23-25$ & 0.641 & 20.5 & 0.32 & 148 & 220 & 1.48 & - & 26 & - \\
\hline $38-2,28-31$ & 0.400 & 12.6 & 0.31 & 151 & 243 & 1.61 & 226 & 32 & 0 \\
\hline $41-2,68-70$ & 0.535 & 18.3 & 0.34 & 180 & 259 & 1.44 & 208 & 41 & 0.2 \\
\hline \multicolumn{10}{|c|}{ 417A Massive Basalts } \\
\hline $43-4,27-30$ & 2.55 & 54.7 & 0.22 & 60 & 99 & 1.64 & 75 & 32 & 2.5 \\
\hline $44-1,52-55$ & & 45.1 & 0.30 & 57 & 115 & 2.02 & 104 & 20 & 0.9 \\
\hline \multicolumn{10}{|l|}{ 417D Pillows } \\
\hline $22-2,107-110$ & 2.01 & 53.0 & 0.26 & 131 & 197 & 1.50 & 186 & 35 & 1.3 \\
\hline $26-7,6-9$ & 1.20 & 39.1 & 0.33 & 144 & 235 & 1.64 & 212 & 19 & 1.4 \\
\hline $28-6,114-117$ & 1.20 & 36.5 & 0.31 & 141 & 222 & 1.57 & - & - & - \\
\hline $30-1,33-36$ & 0.541 & 19.0 & 0.35 & 274 & 450 & 1.65 & 257 & 28 & 1.0 \\
\hline $32-1,62-65$ & 0.772 & 27.9 & 0.36 & 239 & 385 & 1.61 & 276 & 31 & 1.1 \\
\hline $34-5,124-126$ & 1.83 & 45.1 & 0.25 & 111 & 180 & 1.63 & 161 & 19 & 1.7 \\
\hline $37-7,21-24$ & 1.10 & 37.9 & 0.34 & 205 & 336 & 1.64 & 262 & 39 & 1.7 \\
\hline $42-1,64-67$ & 0.655 & 18.0 & 0.28 & 174 & 294 & 1.69 & 216 & 9 & 5.1 \\
\hline $44-1,46-49$ & 2.54 & 46.2 & 0.18 & 73 & 125 & 1.71 & 53 & 20 & 5.5 \\
\hline $45-1,27-30$ & 2.57 & 53.2 & 0.21 & 76 & 121 & 1.59 & 54 & 19 & 3.5 \\
\hline $54-4,55-57$ & 3.46 & 70.0 & 0.20 & 64 & 98 & 1.53 & 48 & 53 & 4.9 \\
\hline $62-7,34-37$ & 1.18 & 32.6 & 0.28 & 145 & 249 & 1.71 & 193 & 17 & 0.5 \\
\hline $64-2,70-72$ & 2.20 & 42.5 & 0.19 & 76 & 136 & 1.79 & 106 & 13 & 1.9 \\
\hline \multicolumn{10}{|c|}{ 417D Massive Basalts } \\
\hline $32-3,12-14$ & 3.15 & 26.5 & 0.08 & 30 & 64 & 2.18 & 29 & 1 & 13.7 \\
\hline $33-2,111-114$ & 3.44 & 35.7 & 0.10 & 38 & 73 & 1.91 & 30 & 3 & 6.9 \\
\hline $34-2,126-129$ & 3.16 & 34.1 & 0.11 & 34 & 67 & 1.94 & 26 & 4 & 10.6 \\
\hline $34-5,100-103$ & 2.27 & 40.1 & 0.18 & 102 & 185 & 1.81 & 173 & 13 & 3.0 \\
\hline $39-2,109-112$ & 3.29 & 59.5 & 0.18 & 71 & 114 & 1.61 & 128 & 2 & 9.5 \\
\hline $43-3,93-96$ & 3.34 & 54.7 & 0.16 & 63 & 109 & 1.74 & 28 & 1 & 13.5 \\
\hline $48-7,31-33$ & 3.31 & 48.7 & 0.15 & 39 & 65 & 1.66 & 35 & 7 & 3.0 \\
\hline $52-1,92-94$ & 3.80 & 49.9 & 0.13 & 52 & 100 & 1.92 & 22 & 24 & 0.7 \\
\hline $59-6,33-35$ & 3.32 & 30.6 & 0.09 & 33 & 74 & 2.24 & 25 & 12 & 1.0 \\
\hline $68-5,89-92$ & 4.21 & 24.8 & 0.06 & 23 & 55 & 2.43 & 17 & 21 & 1.3 \\
\hline
\end{tabular}

Note: $J_{\mathrm{S}}=$ isothermal saturation magnetization in $\mathrm{emu} / \mathrm{cm}^{3} ; \mathrm{J}_{\mathrm{rs}}=$ saturation remanent magnetization in $10^{-2} \mathrm{emu} / \mathrm{cm}^{3} ; \mathrm{H}_{\mathrm{c}}=$ bulk coercivity in $\mathrm{Oe} ; \mathrm{H}_{\mathrm{cr}}=$ coercivity of remanence in Oe; $\mathrm{MDF}=$ median destructive field in $\mathrm{Oe} ; \mathrm{Q}=$ Königsberger ratio; $v=$ viscosity coefficient in per cent.

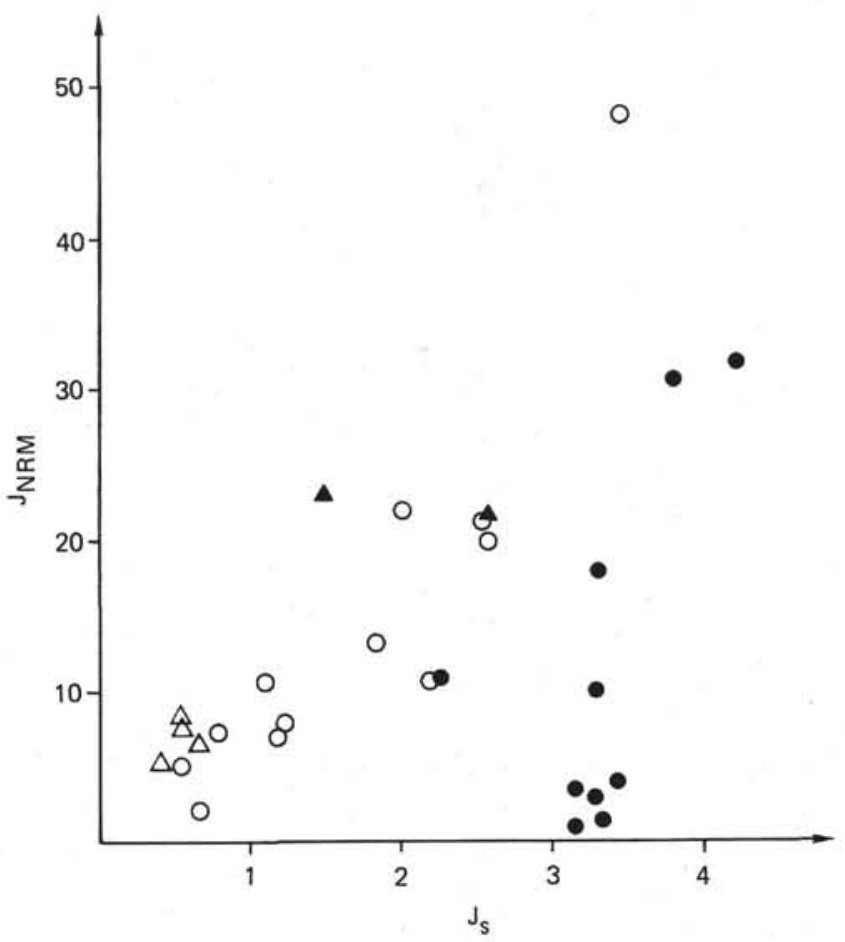

Figure 8. Relationship between natural remanent magnetization intensity $J_{N R M}\left(\times 10^{-3} \mathrm{emu} / \mathrm{cm}^{3}\right)$ and isothermal saturation magnetization $J_{s}\left(\mathrm{emu} / \mathrm{cm}^{3}\right)$ for Site 417 basement samples. Same symbols as for Figure 7.

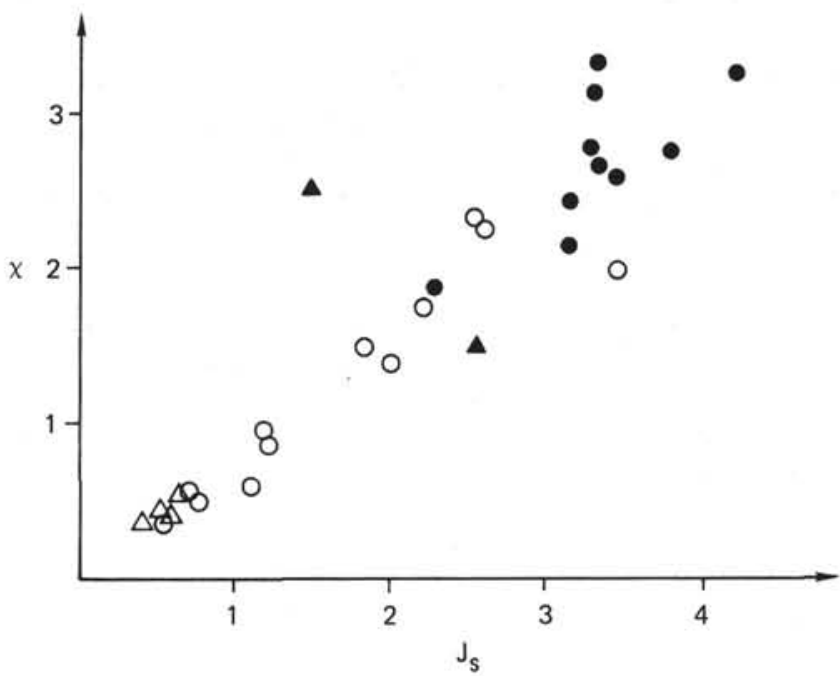

Figure 9. Relationship between initial susceptibility $\chi(\mathrm{X}$ $10^{-3} \mathrm{emu} / \mathrm{cm}^{3}$. Oe and isothermal saturation magnetization $J_{s}\left(\mathrm{emu} / \mathrm{cm}^{3}\right)$ for Site 417 basement samples. Same symbols as for Figure 7.

$\mathrm{H}_{\mathrm{cr}} / \mathrm{H}_{\mathrm{c}}=1.09$ (Stoner and Wohlfarth, 1948). On synthetic samples of non oxidized SD titanomagnetites, Day et al. (1977) obtained values $\mathrm{H}_{\mathrm{cr}} / \mathrm{H}_{\mathrm{c}}$ of 1.2 to 1.5 . For larger grains, $\mathrm{H}_{\mathrm{cr}} / \mathrm{H}_{\mathrm{c}}$ increases through the PSD range up to about 3.5 for the PSD to MD transition size (Rahman and Parry, 1978)

At Site 417 , values of $\mathrm{Hcr}_{\mathrm{c}} / \mathrm{Hc}$ are generally those of PSD grains. In the pillows of both holes, $\mathrm{Hcr} / \mathrm{Hc}$ is only slightly 


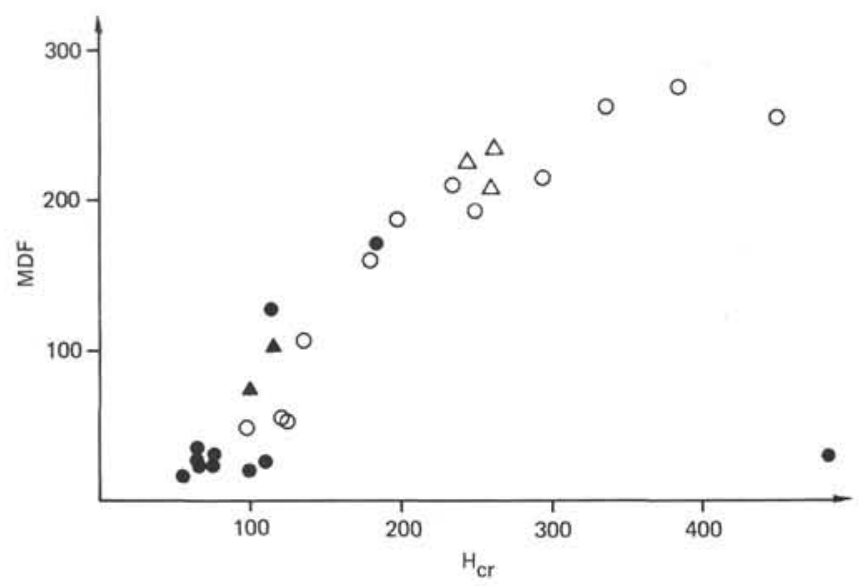

Figure 10. Relationship between the median destructive field $M D F(O e)$ and the coercivity of remanence $H_{c r}$ (Oe) for Site 417 basement samples. Same symbols as for Figure 7.

higher than values experimentally found on synthetic samples of SD grains and is close to the values obtained on dredged pillow basalts from the FAMOUS area (Lecaille and Prévot, in preparation). Because SPM particles are very likely to be present in the pillows, particularly in those of Hole 417D as indicated by the viscosity coefficients, it is not surprising that obtained values of $\mathrm{H}_{\mathrm{cr}} / \mathrm{H}_{\mathrm{c}}$ and $\mathrm{J}_{\mathrm{r} s} / \mathrm{J}_{\mathrm{s}}$ are not truly SD values, although the magnetic minerals should be mainly in the single domain state.

$\mathrm{Hcr} / \mathrm{H}_{\mathrm{c}}$ increases in the massive basalt samples, reaching the highest values at the bottom of Hole 417D where crystallization is advanced. Even here, however, $\mathrm{Hcr} / \mathrm{Hc}$ values are not strictly MD values, which suggests, as does the $\mathrm{J}_{\mathrm{rs}} / \mathrm{J}_{\mathrm{s}}$ data, that the samples contain a mixture of PSD and MD magnetic grains. Figure 11 summarizes the magnetic grain size effects at Site 417 by the relationship between $\mathrm{Hcr} / \mathrm{H}_{\mathrm{c}}$ and $\mathrm{J}_{\mathrm{r} s} / \mathrm{J}_{\mathrm{s}}$.

\section{SUMMARY AND CONCLUSIONS}

The pillows and the massive basalts in the Cretaceous crust at Site 417 are lithologically and structurally different and also constitute two distinct populations in terms of magnetic properties. As a result of the emplacement mode, the magnetic minerals are smaller, less abundant, and more strongly low-temperature oxidized in the pillows than in the massive basalts.

An increase in the magnetic grain size is correlated with an increase in the volume percentage of the magnetic oxides and generally by a lower degree of oxidation as illustrated by the massive basalt samples from the dike injection zone of Hole 417D.

For the pillows, the relatively high values of JNRM, Q, MDF, $\mathrm{J}_{\mathrm{r} s} / \mathrm{J}_{\mathrm{s}}$, and $\mathrm{H}_{\mathrm{c}}$, and the low values of $\chi, \mathrm{v}$, and $\mathrm{Hcr} / \mathrm{Hc}_{\mathrm{c}}$ can be interpreted in terms of SD to PSD magnetic grains. In some pillow samples from Hole 417D, the viscosity coefficient is significant and may be accounted for by the presence of a fraction of SD grains close to the SPM threshold, as suggested by high values of $\chi$. In the samples studied here, the size range and consequently the volume percent of the magnetic oxides appear to be more variable

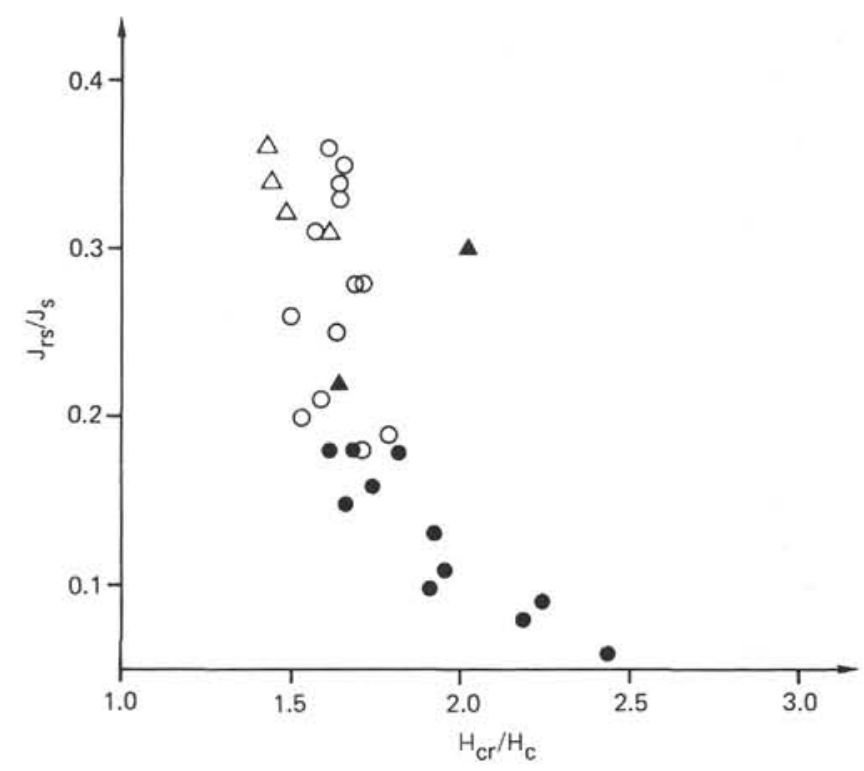

Figure 11. Relationship between the ratios $J_{r s} / J_{S}$ and $H_{c r} /$ $H_{c}$ for Site 417 basement rocks. Same symbols as for Figure 7.

within the relatively fresh pillows of Hole 417D than in the highly altered pillow sequence of Hole 417A.

In the massive units, the low values of $\mathrm{Q}, \mathrm{MDF}, \mathrm{J}_{\mathrm{r}} / \mathrm{J}_{\mathrm{s}}$, and $\mathrm{Hc}$ and the relatively high values of $\chi, \mathrm{v}$, and $\mathrm{Hcr} / \mathrm{Hc}$ are interpreted in terms of PSD to MD magnetic grains, the latter being more abundant in the dike injection zone at the bottom of Hole 417D. As a result of the opposing effects of increasing abundance and increasing grain size in the PSD to MD range of the magnetic oxides, $\mathrm{J}_{\mathrm{NRM}}$ is found to be conspicuously different in the two holes. With a comparable chemistry and a slightly larger proportion of magnetic oxides in Hole 417D than in Hole 417A, J JRM is nevertheless appreciably lower in the former. This can be attributed to be presence of larger MD grains in Hole 417D being responsible for a high viscosity coefficient and a VRM acquired in situ with a direction opposite to the reverse primary TRM.

Low-temperature oxidation may cause some of the initially stable SD carriers of remanence to become superparamagnetic, either by effective size reduction of the titanomagnetites through fragmentation by volume change cracks, or by relaxation of grains with initially low blocking temperatures. For typical titanomagnetites in oceanic basalts with a composition $x=0.6$, both magnetocrystalline and shape anisotropy are known to decrease with increasing cation deficiency whereas stress anisotropy would decrease with the development of volume change cracks inside the magnetic grains. Consequently, due to both physical and intrinsic effects, maghemitization of titanomagnetites is expected to reduce the coercivity. These mechanisms may account for the factor of two observed between the $\mathrm{H}_{\mathrm{c}}$ of pillows from Site 417 with highly oxidized titanomagnetites and values recorded for dredged basalts with non oxidized magnetic minerals.

The high values of $\mathrm{J}_{\mathrm{NRM}}$ are doubtless unusual considering all of the factors acting against their retention. The basalt sections of Site 417 are dominated by the occurrence of 
pillow basalts whose magnetic minerals are strongly low-temperature oxidized. This cation deficiency is well

known to produce:

1) Intrinsic decrease of $J_{s}$,

2) Increase of the SPM fraction at the expense of SD magnetic grains,

3) Eventual reduction of the volume of magnetic material by production of a non magnetic phase at the expense of initially ferrimagnetic minerals.

Furthermore, the emplacement of the Cretaceous basalt sequences of Site 417 took place near $11^{\circ} \mathrm{N}$. Since the geomagnetic field intensity varies with latitude, it is likely that the field intensity was lower during the cooling of the Site 417 basalts than for most other oceanic basalts investigated to date (the majority were dredged or drilled at higher paleolatitudes) unless the Earth's field was abnormally high 105 to 110 m.y. B.P.

In view of these facts, the present study of Cretaceous oceanic basalts from Site 417 suggests that only an exceptionally high magnetic oxide content can account for the high values of remanent magnetic intensity encountered.

\section{ACKNOWLEDGMENTS}

We are grateful to N. Petersen for critical comments on the manuscript. U. Bleil wishes to acknowledge the financial support by the Deutsche Forschungsgemeinschaft, and B. Smith the Center National pour l'Exploitation des Océans, for financial support.

\section{REFERENCES}

Ade-Hall, J.M. and Johnson, H.P., 1976. Paleomagnetism of basalts, Leg 34. In Hart, S.R., Yeats, R.S., et al., Initial Reports of the Deep Sea Drilling Project, v. 34: Washington (U.S. Government Printing Office), p. 513-532.

Ade-Hall, J.M., Johnson, H.P. and Ryall, P.J.C., 1976. Rock magnetism of basalts, Leg 34. In Hart, S.R., Yeats, R.S., et al., Initial Reports of the Deep Sea Drilling Project, v. 34: Washington (U.S. Government Printing Office), p. 459-468.

Bleil, U. and Petersen, N., 1977. Magnetic properties of basement rocks, Leg 37, Site 332. In Aumento, F., Melson, W.G., et al., Initial Reports of the Deep Sea Drilling Project, v. 37: Washington (U.S. Government Printing Office), p. 449-456.

Butler, R.F., 1973. Stable single-domain to superparamagnetic transition during low-temperature oxidation of oceanic basalts, J. Geophys. Res., v. 78 , p. 6868-6876.

Day, R., Fuller, M., and Schmidt, V.A., 1977. Hysteresis properties of titanomagnetites: Grain size and compositional dependence, Phys. Earth Planet. Int., v. 13, p. 260-267.

Day, R., Halgedahl, S., Steiner, M., Kobayashi, K., Furuta, T., Ishii, T., and Faller, A., 1979. Magnetic properties of basalts from DSDP Leg 49. In Luyendyk, B., Cann, J.R., et al., Initial Reports of the Deep Sea Drilling Project, v. 49: Washington (U.S. Government Printing Office), p. 781-792.

Dunlop, D.J. and Hale, C.J., 1977. Simulation of long-term changes in the magnetic signal of the oceanic crust, Can. J. Earth Sci., v. 14, p. 716-744.

Grommé, S. and Mankinen, E.A., 1976. Natural remanent magnetization, magnetic properties, and oxidation of titanomagne- tite in basaltic rocks from DSDP Leg 34. In Hart, S.R., Yeats, R.S., et al., Initial Reports of the Deep Sea Drilling Project, v. 34: Washington (U.S. Government Printing Office), p. 485494.

Herpin, A., 1968. Théorie du magnétisme: Paris (Presse universitaire de France), p. 769.

Irving, E., Park, J.K., Haggerty, S.E., Aumento, F., and Loncarevic, B., 1970. Magnetism and opaque mineralogy of basalts from the mid-Atlantic ridge at $45^{\circ} \mathrm{N}$, Nature, v. 228 , p. 974-976.

Johnson, H.P., 1979. Rock magnetic properties of igneous rock samples - Leg 45. In Melson, W.G., Rabinowitz, P.D., et al., Initial Reports of the Deep Sea Drilling Project, v. 45: Washington (U.S. Government Printing Office), p. 397-406.

Lecaille, A. and Prévot, M., in preparation. Rock magnetism of FAMOUS rift valley pillow basalts and implications for magnetization of oceanic crust.

Lowrie, W., 1974. Oceanic basalt magnetic properties and the Vine and Matthews hypothesis, J. Geophys., v. 40, p. 513-536.

Marshall, M. and Cox, A., 1972. Magnetic changes in pillow basalt due to sea floor weathering. J. Geophys. Res., v. 77, p. 6459-6469.

Murthy, G.S., Deutsch, E.G., and Pätzold, R.R., 1976. Inferences on the magnetic domain state of Leg 37 basalts, J. Geophys. Res., v. 81 , p. 4199-4206.

Néel, L., 1954. Remarques sur la théorie des propriétés magnétiques des substances dures, Appl. Sci. Res., v. 4, p. 13-24.

O'Donovan, J.B. and O'Reilly, W., 1977. The preparation, characterization and magnetic properties of synthetic analogues of some carriers of the paleomagnetic record, J. Geomag. Geoelectr., v. 29, p. 331-344.

Petersen, N., 1979. Rock- and paleomagnetism of basalts from Site 396B, Leg 46. In Dmitriev, L., Heirtzler, J., et al., Initial Reports of the Deep Sea Drilling Project, v. 46: Washington (U.S. Government Printing Office), p. 357-362.

Petersen, N., Bleil, U., and Eisenach, P., 1978. Rock- and paleomagnetism of Leg 42 basalts. In Hsü, K.T., Montadert, L., et al., Initial Reports of the Deep Sea Drilling Project, v. 42, Part 1: Washington (U.S. Government Printing Office), p. 881-886

, in press. Rock- and paleomagnetism of Leg 43 basalts. In Tucholke, B., Vogt, P.R., et al., Initial Reports of the Deep Sea Drilling Project, v. 43: Washington (U.S. Government Printing Office).

Rahman, A.A. and Parry, L.G., 1978. Titanomagnetites prepared at different oxidation conditions: Hysteresis properties, Phys. Earth Planet. Int., v. 16, p. 232-239.

Ryall, P.J.C., Hall, J.M., Clark, J., and Milligan, T., 1977. Magnetization of oceanic crustal layer 2 - results and thoughts after DSDP Leg 37, Can. J. Earth Sci., v. 14, p. 684-706.

Stoner, E.C. and Wohlfarth, E.P., 1948. A mechanism of magnetic hysteresis in heterogeneous alloys, Phil. Trans. Roy. Soc., v. 240 , p. $599-642$.

Thellier, E. and Thellier, O., 1959. Sur l'intensité du champ magnétique terrestre dans le passé historique et géologique, Ann. Géophys., v. 15, p. 285-376.

Watkins, N.D., Paster, T., and Ade-Hall, J., 1970. Variation of magnetic properties in a single deep-sea pillow basalt, Earth Planet Sci. Lett., v. 8, p. 322-328. 